\title{
MICROBIAL KINETIC CONTROLS ON CALCITE MORPHOLOGY IN SUPERSATURATED SOLUTIONS
}

\author{
TANJA BOSAK AND DIANNE K. NEWMAN \\ Division of Geological and Planetary Sciences, California Institute of Technology, Pasadena, California 91125, U.S.A. \\ e-mail:dkn@gps.caltech.edu
}

\begin{abstract}
Recognizing microbial imprints in the morphology of calcium carbonate minerals that form in very supersaturated solutions containing a high level of dissolved inorganic carbon (DIC) is challenging. To better define criteria for this purpose, we have analyzed the influence of sulfate-reducing bacterium Desulfovibrio desulfuricans strain G20 on the morphology of calcite in such solutions. G20 does not induce large shifts of $\mathrm{pH}$ or alkalinity under these conditions, but its uptake of millimolar sulfate and lactate decreases the number of anhedral crystals and stimulates growth of subhedral spar crystals relative to the abiotic controls. In addition, organic compounds associated with the basal growth medium, purified exopolymeric substances produced by G20 and lypopolysaccharide, stimulate the growth of anhedral crystals and crystals with rounded edges at low supersaturation index (SI) of calcite. The effect of organic compounds is reduced at higher SI, where rhombohedral habits dominate. Our results suggest that the local production and uptake of kinetic inhibitors within microbial biofilms may be an important control on calcite morphology in supersaturated solutions.
\end{abstract}

\section{INTRODUCTION}

Finding unique microbial morphological biomarkers in the most ubiquitous calcium carbonate minerals (calcite and aragonite) is a challenging but essential step toward understanding the parallel evolution of life and the environment on Earth (Grotzinger and Knoll 1999), and beyond (Thomas-Keprta et al. 1998). Microbial signatures in these minerals are often only putative because a variety of biological and abiotic processes can readily alter the solution chemistry and result in similar carbonate morphologies.

In inorganic solutions that contain only calcium and carbonate salts, the amount and the morphology of calcium carbonate minerals depend on the supersaturation index (SI) of these minerals and their precipitation rate (Fernández-Díaz et al. 1996; Given and Wilkinson 1985; Gonzalez et al. 1992). The supersaturation index [SI] of a mineral is a measure of how much a solution departs from the thermodynamic equilibrium with respect to the precipitation of that mineral (Stumm and Morgan 1996). The SI of calcite is defined as $\log \left(\mathrm{IAP} / \mathrm{K}_{\mathrm{s}}\right)$, where IAP is the ionic product of calcium and carbonate and $\mathrm{K}_{\mathrm{s}}$ is the solubility constant of calcite $\left(\mathrm{K}_{\mathrm{s}}=10^{-8.48}\right)$. The same analysis applies to other polymorphs of calcium carbonate such as aragonite, taking into account their different solubility constants $\left(\mathrm{K}_{\mathrm{s}}\right.$ for aragonite is 8.33). Most natural solutions contain ions such as magnesium, sulfate, and phosphate that act as kinetic inhibitors of calcite precipitation and alter its morphology (Berner and Morse 1974; Davis et al. 2000; Fernández-Díaz et al. 1996; Tracy et al. 1998).

Multiple microbial mechanisms can influence the amount and shape of calcium carbonate minerals in solutions that are not highly supersaturated with respect to calcium carbonate such as modern seawater and marine sediments, caves, and soils. Microbes can change the SI of calcium carbonates, take up and secrete various kinetic inhibitors, or bind calcium and magnesium ions on their negatively charged outer surfaces (Braissant et al. 2003; Buczynski and Chafetz 1991; Contos et al. 2001; Kawaguchi and Decho 2002; Krumbein 1978; Roberts et al. 2004; Rodríguez-Navarro et al. 2003; Schultze-Lam et al. 1996; Van Lith et al. 2003; Visscher et al. 2000; Warthmann et al. 2000). In highly supersaturated environments that contain a lot of dissolved inorganic carbon (DIC) such as soda lakes and hot springs, microbial biofilms can leave morphological signatures (Arp et al. 1998; Arp et al. 1999; Chafetz et al. 1991; Folk et al. 1985), although the amount of precipitated carbonates is not predicated upon metabolic shifts of SI (Arp et al. 2001; Bosak and Newman 2003). Some of these signatures have been confirmed by laboratory experiments (Bosak et al. 2004), but how various microbes interact with carbonate minerals in the presence of high DIC deserves more experimental attention.

Investigating the effects of sulfate reduction on calcite precipitation in a medium with high initial SI, high DIC, and little sulfate, we noticed that calcite crystals in the cultures of metabolically active Desulfovibrio desulfuricans strain G20 had different shapes than the crystals in the G20 growth medium without bacteria. Because carbonate rocks from the early Earth apparently precipitated from much more supersaturated solutions that contained little sulfate relative to the modern-day oceans (Anbar and Knoll 2002; Grotzinger and James 2000; Grotzinger and Knoll 1999; Habicht et al. 2002), little sulfate and high DIC in our experimental solutions are relevant not only for modern-day high-DIC environments but also for the early Earth. Here we describe some of the mechanisms by which G20, its cellular fractions, and its metabolites can alter calcite morphology as an initial step in the development of a model system in which to study interactions between biofilms and accreting carbonate minerals. Our objective is to understand the relative importance of inorganic versus microbial processes that influence the formation of calcite crystal habits in solutions where substantial precipitation occurs regardless of microbial activity.

\section{MATERIALS AND METHODS}

\section{Bacterial Strain, Culture Medium, and Experimental Conditions}

D. desulfuricans strain G20 was generously provided by Judy Wall (University of Missouri). All precipitation experiments were carried out under an anaerobic atmosphere of $0.8 \mathrm{~atm} \mathrm{~N}_{2}, 0.15 \mathrm{~atm} \mathrm{CO}_{2}$, and $0.05 \mathrm{~atm} \mathrm{H}_{2}$ in bicarbonate-buffered anaerobic $\mathrm{G} 20$ basal medium at $25^{\circ} \mathrm{C}$. The composition of the basal medium is described in Table 1. The SI of our solutions was changed either by changing the $\mathrm{pH}$ of the medium (thus changing the amount of carbonate ion) or by modifying the activity of the calcium ion. To that end, we either established the $\mathrm{pH}$ from 6.8 to 8.0 in aliquots of the basal medium by adding $1 \mathrm{~N} \mathrm{HCl}$ or $10 \mathrm{~N} \mathrm{NaOH}$ or added $\mathrm{CaCl}_{2}$ to aliquots of the basal medium to a final concentration from 5 to $20 \mathrm{mM}$ at a constant $\mathrm{pH}$ (7.5). While these $\mathrm{pH}$ values are lower than some estimates of the marine $\mathrm{pH}$ in the Precambrian (Arp et al. 2001), they are consistent with the estimates of Grotzinger and Kasting (1993) and the high $\mathrm{pCO}_{2}$ inferred by Ohmoto et al. (2004). $20 \mathrm{mM}$ calcium concentration is high relative to the modern seawater $(10 \mathrm{mM})$, but calcium concentrations even higher than $20 \mathrm{mM}$ are consistent with calcium levels required to support the calcification of cyanobacterial filaments at various times in the Earth's history (Arp et al. 2001).

The standard G20 growth (and precipitation) medium contained $1 \mathrm{mM}$ sulfate and 3 or $10 \mathrm{mM}$ lactate (further specified in the text). Although much higher concentrations of sulfate and lactate $(\sim 20 \mathrm{mM}$ and $\sim 50$ $\mathrm{mM}$, respectively) are commonly used to grow sulfate-reducing bacteria, we used these low concentrations in keeping with the low sulfate concentrations inferred for the Precambrian oceans (Anbar and Knoll 2002; Habicht et al. 2002) and our previous work that investigated the influence of sulfate reduction on carbonate precipitation in such oceans (Bosak and Newman 2003). Microscopic counts of cells stained by 4',6-Diamidino-2phenylindole (DAPI) (Sigma-Aldrich) confirmed that biomass doubling could occur even with $1 \mathrm{mM}$ sulfate in the medium. 

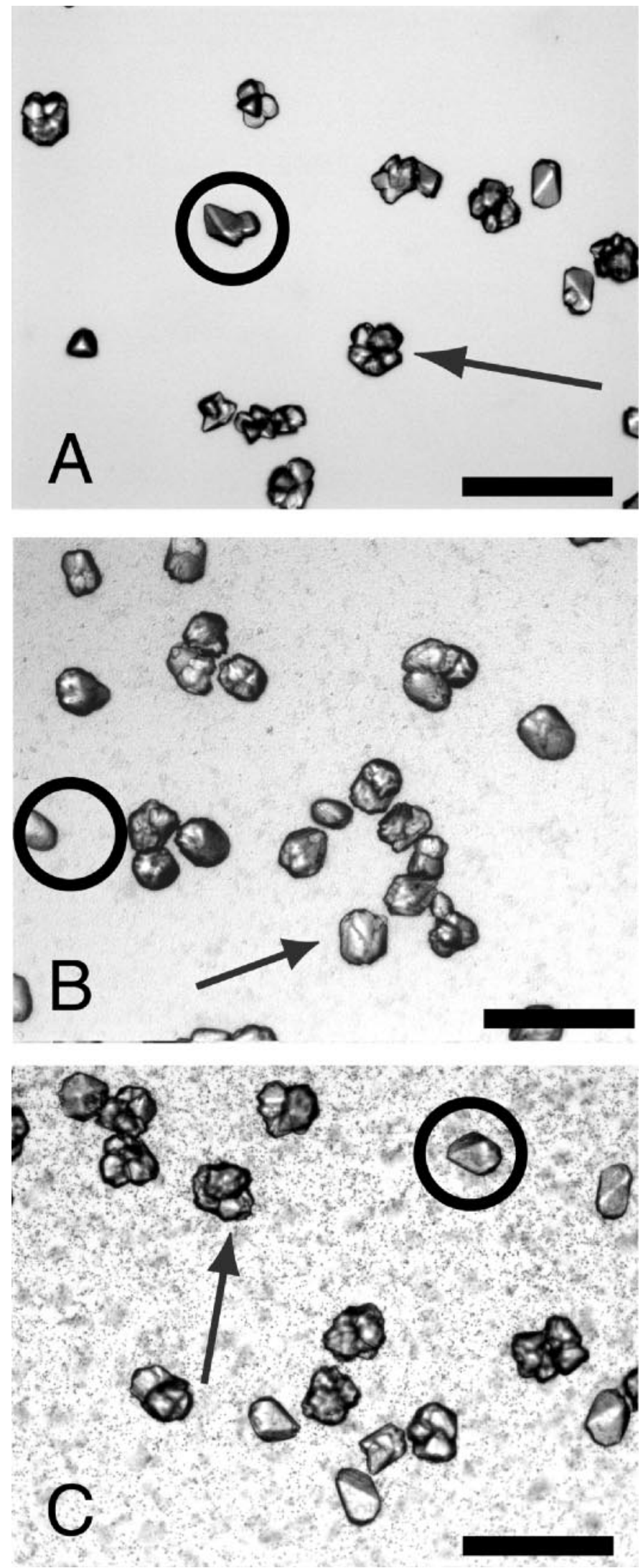

FIG. 1.-Calcite morphology in the presence of metabolically active G20 differs from that in sterile and UV-inhibited controls. The arrows in all images indicate typical rhombohedral crystals and twins. The circles in all images indicate spar
To investigate the effect of organic additives in the basal medium on calcite morphology, we made a solution that contained all of the inorganic constituents (Table 1) but lacked the organic compounds (yeast extract, vitamins, cysteine, and lactate). We conducted precipitation experiments in aliquots of the inorganic basal medium whose initial $\mathrm{pH}$ varied from 6.4 to 8.2. This experiment was repeated twice.

To obtain a dense bacterial inoculum for the precipitation experiments, G20 was grown with $3 \mathrm{mM}$ Na-sulfate (growth-limiting concentration) and $10 \mathrm{mM}$ Na-lactate as the electron acceptor and donor, respectively. The UV treatment consisted of exposing bacteria to UV light for 5 minutes on a Foto/Convertible ${ }^{\mathbb{T M}}$ transilluminator (Fotodyne Incorporated). To assay the metabolic activity of UV-treated cells, we measured lactate and acetate concentrations in untreated and UV-treated G20 cultures (with $3 \mathrm{mM}$ initial sulfate and $10 \mathrm{mM}$ lactate) by Waters 717plus Autosampler HPLC (highperformance liquid chromatograph) with an Aminex ${ }^{\circledR} \mathrm{HPX}-87 \mathrm{H}$ column by BioRad.

\section{Extraction of 620 Cellular Fractions}

We extracted the exopolymeric substances (EPS) produced by G20, its outer envelopes, and the lypopolysaccharide (LPS) fraction of the outer cell membrane to compare and contrast their in vitro effects on calcite morphology.

To precipitate EPS, we grew 11 of G20 with $20 \mathrm{mM} \mathrm{Na}$-sulfate and 50 $\mathrm{mM}$ Na-lactate to a cell density of $1.5 \times 10^{8}$ cells $/ \mathrm{ml}$. The early stationary culture was then spun at $10,000 \mathrm{~g}$ at $4^{\circ} \mathrm{C}$, the supernatants were mixed with 3 volumes of cold isopropanol $\left(4^{\circ} \mathrm{C}\right)$ and left to precipitate for 3 days at $4^{\circ} \mathrm{C}$ (Beech et al. 1991). Precipitated EPS were dialyzed for 48 hours with nanopure water in a SpectraPor dialysis membrane with MS3500 molecular cutoff (Spectrum Laboratories, Inc.). Dialyzed EPS were lyophilized and stored at $-80^{\circ} \mathrm{C}$.

To isolate the outer membranes from cultures in early stationary phase $\left(1.5 \times 10^{8}\right.$ cells $\left./ \mathrm{ml}\right)$, we centrifuged 11 of cells in $0.05 \mathrm{M}$ HEPES $(\mathrm{pH}$ $7.5)$ at $10,000 \mathrm{~g}$ at $4^{\circ} \mathrm{C}$ for 30 minutes. Cell suspension $(3 \mathrm{~g} / 10 \mathrm{ml}$ of 0.05 $\mathrm{M}$ HEPES) was then incubated on ice for 2 hours and centrifuged at 5,000 $g$ and $4^{\circ} \mathrm{C}$ for 30 minutes (Feio et al. 1998). G20 was resuspended in 10 $\mathrm{ml}$ of $0.05 \mathrm{M}$ HEPES to which we added $50 \mu \mathrm{g} / \mathrm{ml}$ DNAse (Roche), 1 $\mathrm{mM} \mathrm{MgCl} 2$, and $10 \mu \mathrm{g} / \mathrm{ml}$ RNAse (Roche). The cell suspension was kept on ice and sonicated for 5 minutes in $30 \mathrm{~s}$ pulses. The unbroken cells were separated from the lysate by centrifugation at 7,000 $\mathrm{g}$ at $4 \mathrm{C}$ for 20 minutes. The cytoplasmic extract was then separated from the cell membranes by ultracentrifugation at 45,000 rpm (SW60 swinging bucket rotor on a Beckman Ultracentrifuge) at $4^{\circ} \mathrm{C}$ (Gerhardt et al. 1994) and the membranes were stored at -20C. LPS was extracted from DNAse-, RNAse-, and lysozymetreated (Sigma) membrane fractions according to Gerhardt et al. (1994), lyophilized, and stored at $-20^{\circ} \mathrm{C}$. The absence of RNA and DNA in the membrane fractions was assayed by measuring the absorbance at 260 and $280 \mathrm{~nm}$ during successive rinses of the membrane fractions in nanopure water on a Beckman DU7400 spectrophotometer.

The protein content of lyophilized EPS was assayed by the Bio-Rad Protein Assay based on the method by Bradford (1976). The amount of neutral carbohydrates in EPS was measured by the $\mathrm{H}_{2} \mathrm{SO}_{4}$-phenol method using glucose as standard (Gerhart et al. 1994). The amount of uronic acids was determined with $m$-hydroxydiphenyl in $\mathrm{H}_{2} \mathrm{SO}_{4}$ /sodium tetraborate so-

crystals with $\{04.1\}$ faces. A) Sterile control without any cells. The twins appear to have grown by reflection on $\{10.4\}$ plane (arrow), and the rhombohedral spar crystals have sharp edges (circle). B) Active G20. Many $\{04.1\}$ rhombohedra (arrow) have stepped faces, and all crystals have more rounded edges (circle). C) Twin and spar crystals in UV-inhibited G20 cultures are similar to the crystals in sterile controls shown in Part A. The dark gray aggregates in the background of Parts B and $\mathrm{C}$ are bacteria. The scale bar in all images is $200 \mu \mathrm{m}$. 

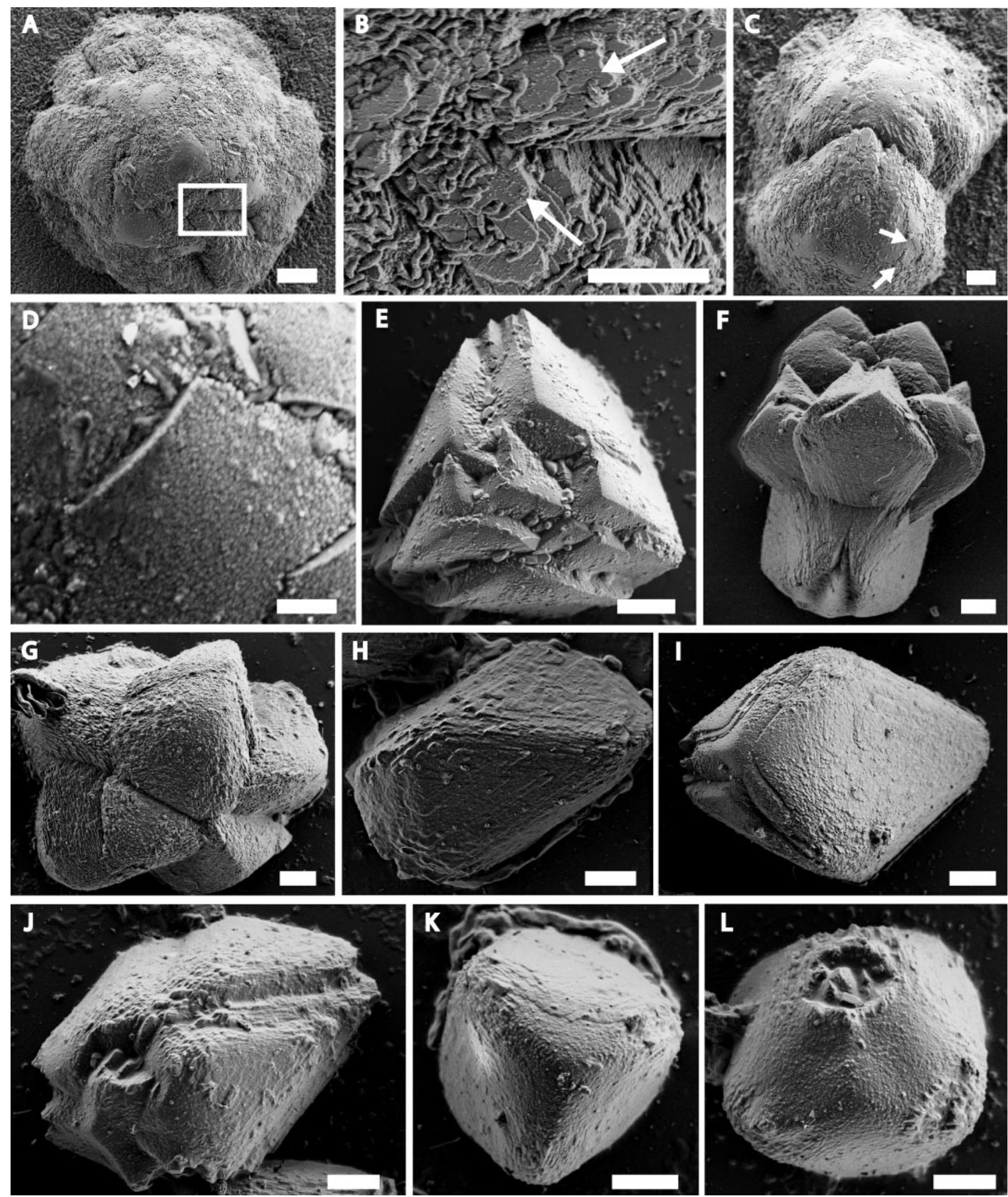

FIG. 2.-Scanning electron micrographs (SEMs) of representative calcite crystals precipitated in the presence of organic compounds in the order of increasing SI. A) Cauliflower-like hemispherical precipitate at low SI $(0.5 \leq \mathrm{SI} \leq 1)$ formed by aggregates of bladed calcite with uneven edges (rectangle shows the area of the close-up in 2B) and stepped curved planes. B) Close-up of Fig. 2A. Bladed calcite crystallites with irregular edges stabilized by organic molecules at low SI. The crystallites are oriented in the same direction only locally but do not aggregate into a recognizable crystal face (arrows). The small, elongated, curved features are G20 cells. The scale bar is $5 \mu \mathrm{m}$. C) Double hemispherical precipitate at $0.5 \leq \mathrm{SI} \leq 1$. The arrows indicate curved planes (see a close-up in Part D). D) Curved, stepped planes are also 
TABLE 1.-Bosak and Newman (2004)

\begin{tabular}{|c|c|c|c|}
\hline Component & $\begin{array}{l}\text { Initial G20 } \\
\text { Growth Medium }\end{array}$ & $\begin{array}{l}\text { G20 Medium } \\
\text { After } 20 \mathrm{~h}\end{array}$ & Comment \\
\hline \multicolumn{4}{|l|}{ Inorganic } \\
\hline $\mathrm{pH}$ & $7.52 \pm 0.01$ & $7.51 \pm 0.01$ & \\
\hline Alkalinity (meq) & $80 \pm 1$ & $77 \pm 1$ & Measured by Gran-titration using $0.8 \mathrm{M} \mathrm{H}_{2} \mathrm{SO}_{4}$ (average of three separate tubes). \\
\hline $\mathrm{Ca}$ & $20.1 \pm 0.8$ & $18.9 \pm 0.2$ & $\begin{array}{l}\text { Measured by ICP-MS (average of three separate tubes). The same decrease in total Ca } \\
\text { was observed in another independent experiment. }\end{array}$ \\
\hline SI & 2.067 & 2.036 & $\begin{array}{l}\text { The SI was modeled by MINEQL+, assuming an equilibrium with } 0.15 \text { atm } \mathrm{CO}_{2} \text { and } \\
\text { titrating by } \mathrm{LiOH} \text { to obtain the measured } \mathrm{pH} \text { (the } \mathrm{pH} \text { of the actual medium was } \\
\text { adjusted by } \mathrm{NaOH} \text { ). The measured changes in } \mathrm{pH}, \mathrm{Ca} \text {, and } \mathrm{C} \text {-alkalinity correspond } \\
\text { well to the expected changes in an open system modeled by MINEQL+. The } \mathrm{pH} \\
\text { of the model medium was calculated by imposing electroneutrality condition. }\end{array}$ \\
\hline $\mathrm{SO}_{4}$ & 1 & ND & $\begin{array}{l}\text { ND: Known concentrations (in mM, unless stated otherwise) were added to the basal } \\
\text { medium and not measured afterward. }\end{array}$ \\
\hline $\mathrm{Cl}$ & 56.5 & ND & Only $\mathrm{Cl}$ that was added with basal salts, more $\mathrm{HCl}$ was added to adjust the $\mathrm{pH}$. \\
\hline $\mathrm{K}$ & 0.5 & ND & \\
\hline $\mathrm{Mg}$ & 8 & ND & \\
\hline $\mathrm{Na}$ & 98 & ND & Only $\mathrm{Na}$ that was added with basal salts, more $\mathrm{NaOH}$ was added to adjust the $\mathrm{pH}$. \\
\hline $\mathrm{NH}_{4}$ & 0.5 & ND & \\
\hline $\mathrm{PO}_{4}$ & 0.05 & ND & \\
\hline SL12-B mineral solution (ml/l) & 1 & ND & http://www.dsmz.de/media/med028.htm \\
\hline \multicolumn{4}{|l|}{ Organic } \\
\hline acetate & 0 & ND & \\
\hline lactate & 10 & ND & \\
\hline yeast extract $(\mathrm{g} / \mathrm{l})$ & 0.15 & ND & \\
\hline cysteine- $\mathrm{HCl}$ & 1.4 & ND & \\
\hline Vitamin solution $(\mathrm{ml} / \mathrm{l})$ & 1 & ND & $\begin{array}{l}4 \mathrm{mg} \text { 4-aminobenzoic acid, } 1 \mathrm{mg} \mathrm{D}(+) \text {-biotin, } 10 \mathrm{mg} \text { nicotinic acid, } 5 \mathrm{mg} \mathrm{Ca}-\mathrm{D}(+)- \\
\text { pantothenate, } 15 \mathrm{mg} \text { pyridoxamine dihydrochloride, } 10 \mathrm{mg} \text { thiaminium dichloride, } \\
\text { and } 5 \mathrm{mg} \text { cyanocobalamine per } 100 \mathrm{ml} \text { nanopure water }\end{array}$ \\
\hline
\end{tabular}

lution using D-glucuronic acid as the standard (Blumenkrantz and Asboehansen 1973). Nucleic acid content in EPS was assayed qualitatively by staining the EPS extract with ethidium bromide in a $2 \%$ agarose gel.

\section{Precipitation Experiments}

To study the influence of G20 metabolism on calcite morphology, 0.5 $\mathrm{ml}$ of untreated or UV-treated late exponential phase bacteria (cell density $5 \times 10^{7}$ cells $/ \mathrm{ml}$ ) were centrifuged to remove the liquid phase. Washed bacteria (either untreated or UV-treated) were resuspended in the fresh culture medium ( $1 \mathrm{ml}$ original culture per $0.8 \mathrm{ml}$ fresh medium) and transferred into 8-well LabTek ${ }^{\circledR}$ (NalgeNunc International) culture dishes with coverslip bottom $(0.4 \mathrm{ml} /$ well). The same amount of sterile medium without bacteria was added to separate wells as a control. In the experiments without bacteria, we added various chemicals or cellular fractions to the sterile medium in the same culture dishes. Finally, $\mathrm{CaCl}_{2}$ was added to each well containing the precipitation medium (with or without cells) to a $20 \mathrm{mM}$ final concentration. The growth of calcite crystals was investigated after 20 hours by transmitted-light microscopy. All precipitation experiments were performed at least twice under each described condition. The calcium concentration was measured by inductively coupled plasma mass spectrometry (ICP-MS) in dilute filtered samples $\left(100 \mu \mathrm{l}\right.$ medium/10 $\left.\mathrm{ml} 1 \% \mathrm{HNO}_{3}\right)$ in triplicates.

\section{Transmitted-Light, Confocal, and Scanning Electron Microscopy}

The morphology of precipitates was examined by taking transmittedlight micrographs from at least 10 different fields of view using a Zeiss Axiovert S100 microscope. The crystals were point-counted to obtain percentages of specific morphologies. The crystals with intermediate mor- phologies were assigned to both end-member morphological classes. All percentages were estimated from at least two independent experiments.

Flourescence confocal microscopy of G20 biofilms was performed on an inverted Zeiss Pascal LSM (laser scanning microscope). The biofilm samples were prepared for imaging as follows: biofilms were grown in the growth medium for $20 \mathrm{~h}$ in 8 -well LabTek ${ }^{\circledR}$ (NalgeNunc International) culture dishes with coverslip bottom, the medium was then replaced by 0.5 M HEPES buffer, $2 \mu$ l dye (Live Dead ${ }^{\circledR}$ BacLight ${ }^{(i W}$ by Molecular Probes) per $0.5 \mathrm{ml}$ buffer, and the biofilms were incubated in the dark for 15 minutes before imaging. The fluorescence of the samples was excited at $488 \mathrm{~nm}$.

EPS and bacteria were stained by the method of Allison and Sutherland (1984).

C-coated precipitates were imaged by a LEO1550 VP field emission scanning electron microscope operating at $2 \mathrm{kV}$ at a $5 \mathrm{~mm}$ working distance.

\section{Mineral Analysis}

The crystal structure of the precipitates was determined by X-ray diffraction using a Scintag diffractometer with $\mathrm{Cu} \mathrm{K} \alpha(\lambda=1.5405 \AA)$. The crystals were washed with $10 \%$ bleach and rinsed in nanopure water before analysis. The crystallinity of samples was determined by looking at the full width of the 104 Bragg calcite peak at half maximum (FWHM) (Klug and Alexander 1954).

\section{Chemical Modeling}

Supersaturation index (SI) and calcium and carbonate activity coefficients in the growth medium (see above) were calculated using MINEQL+

$\leftarrow$

stabilized by organic additives in the basal medium at low SI. The scale bar is $3 \mu \mathrm{m}$. E) About $10 \%$ of the crystals at low SI had stabilized $\{10.0\}$ faces. F) Twin (most likely on $\{01.2\}$ ) with stabilized $\{10.0\}$ faces and negative faces (arrow) that forms at $1 \leq \mathrm{SI} \leq 1.5$. G) Twin (probably on $\{10.4\}$ ) of rhombohedral crystals, $1 \leq \mathrm{SI}$ $\leq 1.5$. H) Truncated spar crystal with stabilized $\{04.1\}$ faces, $1.2 \leq$ SI. I) Elongated rhombohedron with stepped growth along $\{10.0\}, 1.5 \leq$ SI $\leq 2.0$. J) Truncated spar crystals with stabilized and stepped $\{04.1\}$ faces form almost $50 \%$ of the precipitate at $2.0 \leq$ SI. K) Rhombohedral habits with a smaller aspect ratio than in Part I form at $2.0 \leq$ SI. L) Truncated rhombohedral habit with stabilized $\{10.0\}$ faces. The scale bar in all images except for Parts B and D is $10 \mu \mathrm{m}$. 


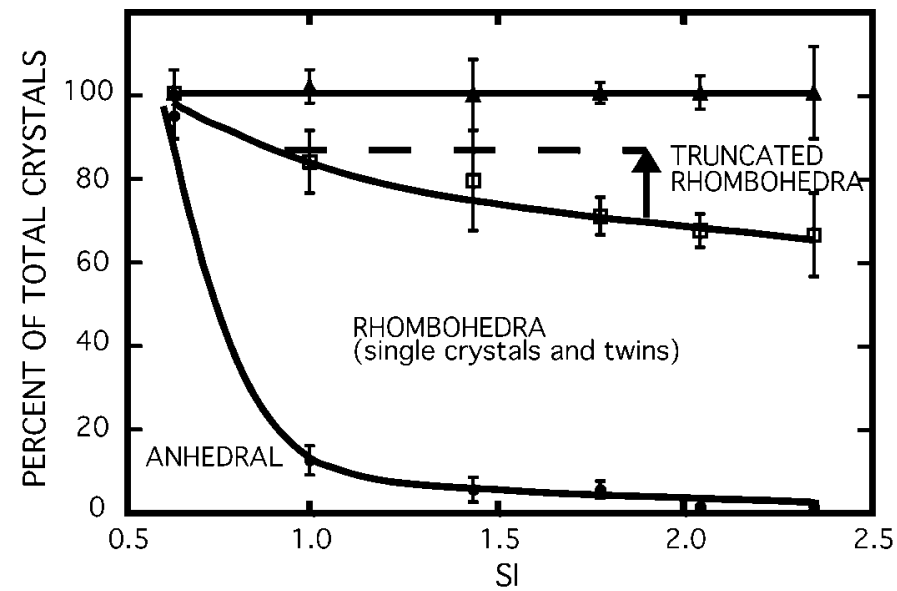

FIG. 3.-Cumulative stability diagram of characteristic calcite habits observed in the basal medium (in the presence of organic compounds, lactate, sulfate, and G20). For any SI the total percentages of crystals add up to $100 \%$, and the lines delineate the fraction of this total that belongs to any particular crystal habit. The relative percentages of crystals habits were obtained by counting the crystals from ten independent fields of view at each SI in two independent experiments. The average percentages of the three major classes measured in two independent experiments are plotted as symbols: anhedral crystals (solid circles), rhombohedral crystals with prominent $\{10.0\}$ faces (hollow rectangles), and truncated rhombohedral crystals with prominent $\{04.1\}$ faces (solid triangles). The error bars show the data range. The solid lines drawn through the points mark the regions of stability of each major class. As the SI increases, the anhedral habits give way to rhombohedra and truncated rhombohedra. The arrow shows the observed difference in $\{04.1\}$ stepped crystals between the sterile controls and G20 cultures at SI $=1.9$ (sterile controls have $\sim 14 \%$ fewer stepped crystals), and the dashed line shows where we would expect the same percentage in G20 cultures (corresponding to $\mathrm{SI}=0.9$ ).

(Environmental Research Software), assuming an open system in equilibrium with $0.15 \mathrm{~atm} \mathrm{CO}_{2}$. The appropriate $\mathrm{pH}$ value was established by numerical titration by $\mathrm{LiOH}$ (to facilitate bookkeeping) or $\mathrm{HCl}$. The composition of the modeled medium (Table 1, but without trace metals, vitamins, yeast extract, and cysteine) was adjusted according to the laboratory experiments (sulfate or lactate concentrations, etc.). The calcite saturation constant used by the program is $\mathrm{K}_{\mathrm{s}}=10^{-8.48}$ and the software calculated the ionic strength of the medium from the supplied concentrations of the ions in the medium, adjusting the equilibrium constants accordingly.

\section{RESULTS AND DISCUSSION}

\section{Calcite Morphology in the Presence of Bacteria}

$\mathrm{X}$-ray diffraction analyses of the powdered samples confirmed that calcite constituted at least $95 \%$ of the calcium carbonate precipitate in G20 basal medium under all tested conditions. Comparing active G20 and sterile controls (without any bacteria) in two independent experiments, we found that $18 \pm 2 \%$ of the total crystals in G20 cultures were truncated rhombohedra with stepped faces as opposed to $3 \pm 1 \%$ in sterile controls (Fig. 1; also see Fig. 2J for an SEM of a representative crystal). Under the transmitted light, the edges of the $\{04.1\}$ rhombohedra in G20 cultures also appeared more rounded relative to the corresponding crystals in sterile controls (Fig. 1A, B, circled). Sterile controls, in turn, contained a higher percentage of anhedral crystals or complex twin aggregates of crystals with stabilized $\{10.0\}$ faces (Fig. 1B and Fig. 2E-G).

To test whether the observed changes were induced by G20's active metabolism, we incubated UV-inhibited G20 at the same cell density as the living G20 and compared the shapes of calcite at the end of the precipitation experiment. The UV-treated cells consumed only $0.79 \pm 0.03$ $\mathrm{mM}$ lactate in $20 \mathrm{~h}$. Because the reduction of 1 mole of sulfate is coupled with the oxidation of 2 moles of lactate, it follows that the UV-treated cells consumed less than $0.5 \mathrm{mM}$ of the available sulfate during the experiment. Lactate and acetate concentrations in the untreated G20 cultures, on the other hand, indicated that all available sulfate was consumed in $20 \mathrm{~h}$. Thus, the UV treatment significantly decreased the ability of G20 to carry out dissimilatory sulfate reduction. Plate counts confirmed that the number of viable cells in UV-treated cultures was at least $10^{6}$ times lower than in the original stock, i.e., there were fewer than $10^{3}$ viable cells per culture well in UV-treated cultures. Given that G20 cell density increases about 10 times in $20 \mathrm{~h}$ (the duration of the precipitation experiment), and that morphological influence of G20 is discernible only at cell densities higher than $10^{7}$ cells $/ \mathrm{ml}$, even if growth occurs in the UV-treated cultures, the effects of less than $10^{4}$ cells $/ \mathrm{ml}$ during the experiment would not be noticeable. Indeed, we found that the precipitate formed in the presence of UV-inactivated bacteria was similar to that in the sterile controls (Fig. 1C).

To understand how active G20 induced these changes in calcite morphology, we wanted to establish whether we could induce comparable changes by varying some basic chemical parameters in the growth medium (SI and the presence of organic molecules and major metabolites).

\section{Effects of Supersaturation, Sulfate, and Lactate on Calcite Morphology in the Absence of Bacteria}

SI as a Control on Calcite Morphology.-Calcite morphology in G20 growth medium is strongly affected by SI. Figure 2 captures the most representative crystal shapes precipitated in the G20 basal medium, although we observed a small number of crystals with intermediate morphologies as well. Overall, as SI increased, the total number of crystals increased and their grain size decreased because of an increase in the number of crystal nuclei. Distinctly anhedral large crystals formed at the lowest $\mathrm{pH}$ values $(0.5 \leq \mathrm{SI} \leq 1)$ (Fig. $2 \mathrm{~A}-\mathrm{D})$. They were roughly hemispherical (because of growth on a flat glass surface), created by stepped aggregates of bladed crystals with irregular edges (Fig. 2A, B) and curved stepped surfaces (Fig. 2C, D). At low to intermediate SI $(1 \leq \mathrm{SI} \leq 1.5)$, less than $10 \%$ of the crystals were distinctly anhedral. Instead, we found stabilized $\{10.0\}$ faces (Fig. 2E-G), negative faces (Fig. 2F), and twinned aggregates (Fig. 2F, G). About $20 \%$ of the total crystals in this SI range were rhombohedra, either truncated, with stabilized $\{04.1\}$ faces (Fig. $2 \mathrm{H}$ ), or elongated, with recognizable $\{10.0\}$ faces (Fig. 2I). Truncated rhombohedral grains with prominently stepped $\{04.1\}$ faces (Fig. 2J) or with $\{10.0\}$ faces (Fig. 2K, L) dominated at even higher initial SI (SI $\geq 2.0$ ). At highest SI (SI $\geq 2.5$ ), most precipitate consisted of intergrown aggregates of $\{10.0\}$ and $\{04.1\}$ rhombohedral grains. We observed this morphological trend both when we varied the total calcium concentration at a constant $\mathrm{pH}$ of 7.5 , and when we varied the $\mathrm{pH}$ at a constant calcium concentration of 20 $\mathrm{mM}$. Figure 3 shows the stability diagram for the three major morphological classes (in the presence of G20).

Metabolic Uptake of Sulfate and Lactate as a Control on Calcite Morphology.-The most commonly described mechanisms by which microbes stimulate calcium carbonate precipitation are the change of local $\mathrm{pH}$ (i.e., by photosynthetic uptake of carbon dioxide or by degradation of amino acids) and an increase in the amount of dissolved carbonate ions. However, in the well-buffered cultures of actively metabolizing G20, pH did not increase and DIC increased by only $2 \pm 1 \mathrm{meq}$ (measured in the absence of calcium) in the background of carbonate alkalinity of $\sim 80$ meq, as could be predicted for G20 cultures limited by $1 \mathrm{mM}$ available sulfate. Consequently, G20 could not increase the SI by more than $0.1 \mathrm{SI}$ units (modeled by MINEQL + using the parameters in Table 1 and changing the total DIC by $2 \mathrm{mM}$, total sulfate by $1 \mathrm{mM}$, and total lactate by 2 $\mathrm{mM}$ ). A much larger increase in SI (about 1 unit) is required to increase the percentage of $\{04.1\}$ crystals by $14 \%$ (Fig. 3), implying that the metabolically induced increase of the alkalinity and the $\mathrm{pH}$ could not account for the observed differences in the shape of calcite crystals between G20 cultures and sterile controls. We therefore decided to test whether calcite 

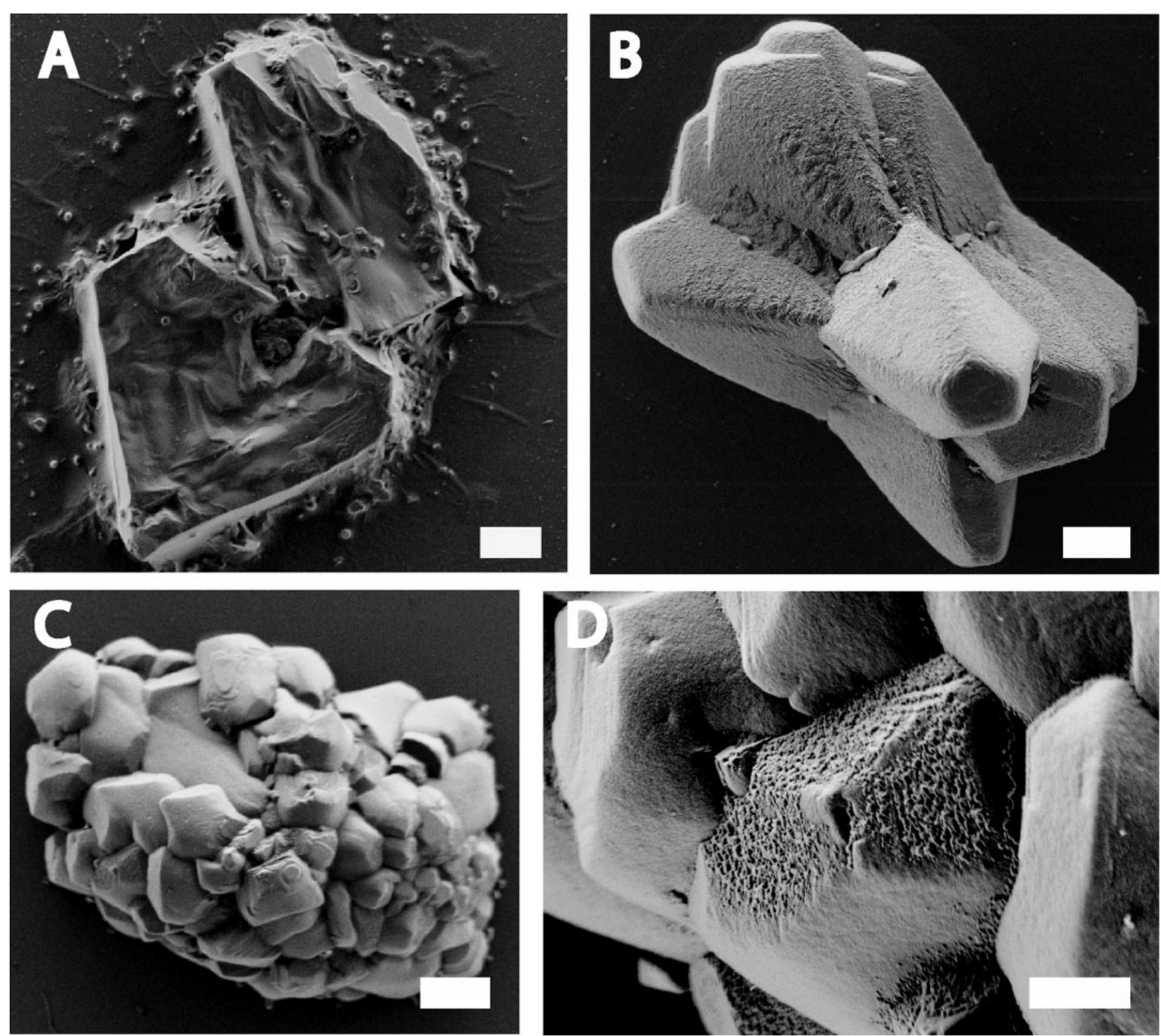

FIG. 4.-SEMs of calcite crystals precipitated in the presence and absence of organics in the basal medium. A) Inorganically precipitated calcite crystal at low SI in the absence of organic molecules. The scale bar is $10 \mu \mathrm{m}$. B) Rhombohedral calcite twin precipitated in the absence of organic additives in the basal medium at intermediate SI. The scale bar is $20 \mathrm{~m}$. C) Framboidal calcite aggregate precipitated at high SI. The scale bar is $20 \mu \mathrm{m}$. D) Rhombohedral calcite crystals within the aggregate from C). The scale bar is $5 \mu \mathrm{m}$.

morphology in the culture medium would change depending on the presence or absence of sulfate and lactate, substrates that are removed in active cultures of G20, but whose concentrations remain constant in sterile controls.

The presence of $2 \mathrm{mM}$ sulfate in the medium without bacteria at SI $=$ 1.2 increased the percentage of anhedral aggregates of bladed calcite (Fig. $2 \mathrm{~A}-\mathrm{D}$ ) by about $50 \%$ relative to the medium without sulfate (two independent experiments). The addition of $3 \mathrm{mM}$ lactate to the basal medium $(\mathrm{SI}=1.5)$ without bacteria reduced the number of truncated rhombohedral aggregates with stepped $\{04.1\}$ faces and spars (Fig. $2 \mathrm{H}, \mathrm{J}$ ) by about $10 \%$ each, and increased the number of aggregates twinned on $\{01.2\}$ and $\{10.4\}$ (Fig. 2F, G) by about $20 \%$ (two independent experiments). The presence of $2 \mathrm{mM}$ sulfate and $5 \mathrm{mM}$ lactate in the medium reduced the crystallinity of calcite by $0.03 \pm 0.01^{\circ} 2 \theta$. Lower crystallinity of the crystals grown with sulfate and lactate indicates either the presence of smaller crystallites or the presence of more crystal defects in the XRD sample. Even higher amounts of sulfate and lactate that are used in standard media for sulfate reducers $(20 \mathrm{mM}$ and $10 \mathrm{mM}$, respectively) reduced the total number of calcite crystals by as much as 50\% (two independent experiments) and stimulated the growth of only hemispherical precipitates (Fig. 2A, D). The growth of calcite in the presence of sulfate and lactate at a given $\mathrm{pH}$ therefore resembled the growth of calcite in the absence of these ions, but at a lower initial $\mathrm{pH}$.

Negatively charged ions like sulfate and lactate can affect calcite morphology by lowering the SI as they complex calcium ions and lower the pool of free calcium ions available for calcite precipitation (Stumm and 

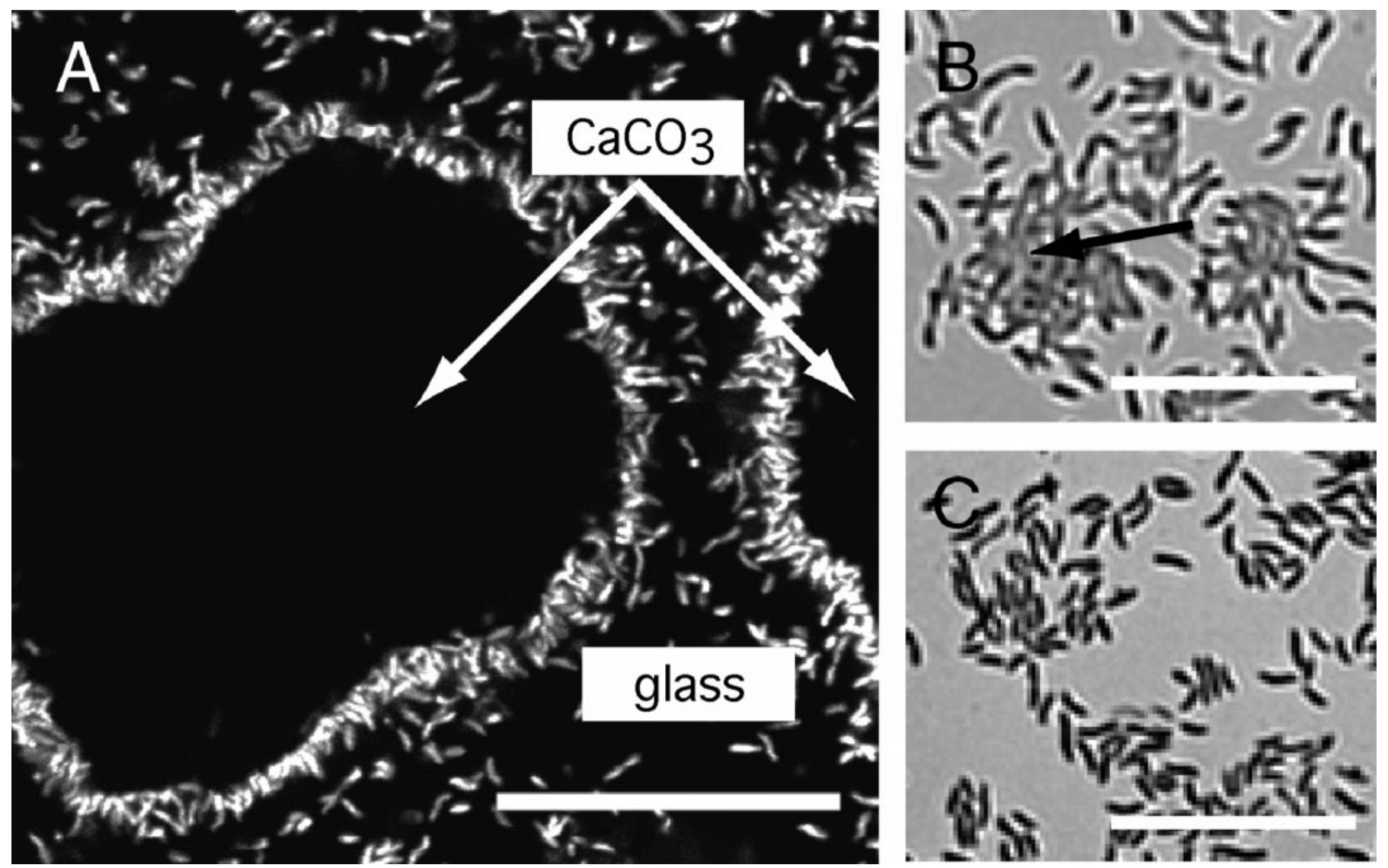

FIG. 5.-G20 forms thin biofilms and secretes exopolymeric substances (EPS) in calcite-precipitating cultures. A) Confocal micrograph showing the attachment of fluorescently stained G20 to calcite crystals (dark dumbbell shapes marked by white arrows). G20 prefers the calcite crystals to the surrounding glass surface. The scale bar is $20 \mu \mathrm{m}$. B) EPS (carbohydrates) were detected only in the centers of denser microcolonies. EPS is the dark gray substance (black arrow). C) Duplicate controls slide with G20 biofilms grown and stained with a general bacterial stain as in Part B. EPS on this slide were not precipitated before staining. The scale bar in Parts B and C is $10 \mu \mathrm{m}$.

Morgan 1996). Alternatively, they can be incorporated into the crystal lattice of growing calcite crystals, kinetically inhibit crystal nucleation, the growth of specific faces (Teng et al. 1998), or increase the number of defects in the crystal lattice. To distinguish between complexation and kinetic inhibition, we modeled the concentration of free calcium ions after complexation by sulfate and lactate in our medium by MINEQL + (assuming the medium composition as described in Table 1 and varying the amount of Na-sulfate and Na-lactate). According to the model, the addition of $3 \mathrm{mM} \mathrm{Na}$-lactate or $2 \mathrm{mM} \mathrm{Na}$-sulfate would reduce the available calcium in the basal medium by less than $0.3 \mathrm{mM}$. Because we had to decrease the initial concentration of calcium in our actual solution by much more (4 $\mathrm{mM}$ ) to reproduce the same morphological changes, we conclude that complexation of the calcium ion by $3 \mathrm{mM}$ lactate or by $2 \mathrm{mM}$ sulfate cannot fully account for the observed changes in the calcite crystal habit. More likely, sulfate and lactate in G20 growth medium inhibit calcite growth kinetically. The observed changes of calcite morphology in active G20 cultures are thus consistent with the removal of sulfate and lactate as kinetic inhibitors.

Hemispherical Crystal Habits Stabilized by Organic Compounds at Low SI.-The prevalence of anhedral, hemispherical crystal habits at the lowest SI (Fig. 2A-D) contrasts many reports of calcite precipitation in inorganic solutions that find or predict spars at low SI, and curved faces and spherical habits at high SI (Fernández-Díaz et al. 1996; Gonzalez et al. 1992; Tiller 1991). We hypothesized that the hemispherical habits at low SI developed under the influence of organic additives $(0.05 \%$ by weight) in the basal medium. Indeed, when all the organic compounds were omitted from the basal medium (see Methods section), we did not observe hemispherical aggregates of bladed calcite (Fig. 4A-D). While inorganically precipitated calcite at high SI formed rounded aggregates (at 50-100 $\mu \mathrm{m}$ scale), the crystallites that formed them were recognizably rhombohedral (Fig. 4C, D). Relatively low amounts $(0.05 \mathrm{wt} \%)$ of organic compounds in solution can thus produce crystal habits that would not be expected in the absence of organics.

Other studies have reported the formation of hemispherical and spherical calcite crystals in the presence of organic molecules and microbes (Braissant et al. 2003; Buczynski and Chafetz 1991; Meldrum and Hyde 2001). Most of these studies found that calcite rhombohedra precipitated in their abiotic control solutions containing only inorganic calcium and carbonate salts (e.g., $\mathrm{CaCl}_{2}$ and $\mathrm{Na}_{2} \mathrm{CO}_{3}$ ). Our inorganic control medium is a more realistic simulation of natural conditions because it contains magnesium, phosphate, sulfate, and trace metals that coexist in many natural waters and are necessary for microbial growth. Although many of these inorganic ions are known to influence the growth and morphology of calcite (Astilleros et al. 2002; Berner and Morse 1974; Fernández-Díaz et al. 1996; Takasaki et al. 1994; Tracy et al. 1998), we did not monitor their concentrations in G20 basal medium after the precipitation experiment (Table 1). Therefore, we cannot discount the possibility that the uptake of trace amounts of inorganic inhibitors (e.g., phosphate) (Berner and Morse 1974) may additionally contribute to the observed differences in calcite morphology between active cultures and controls (Fig. 1). 

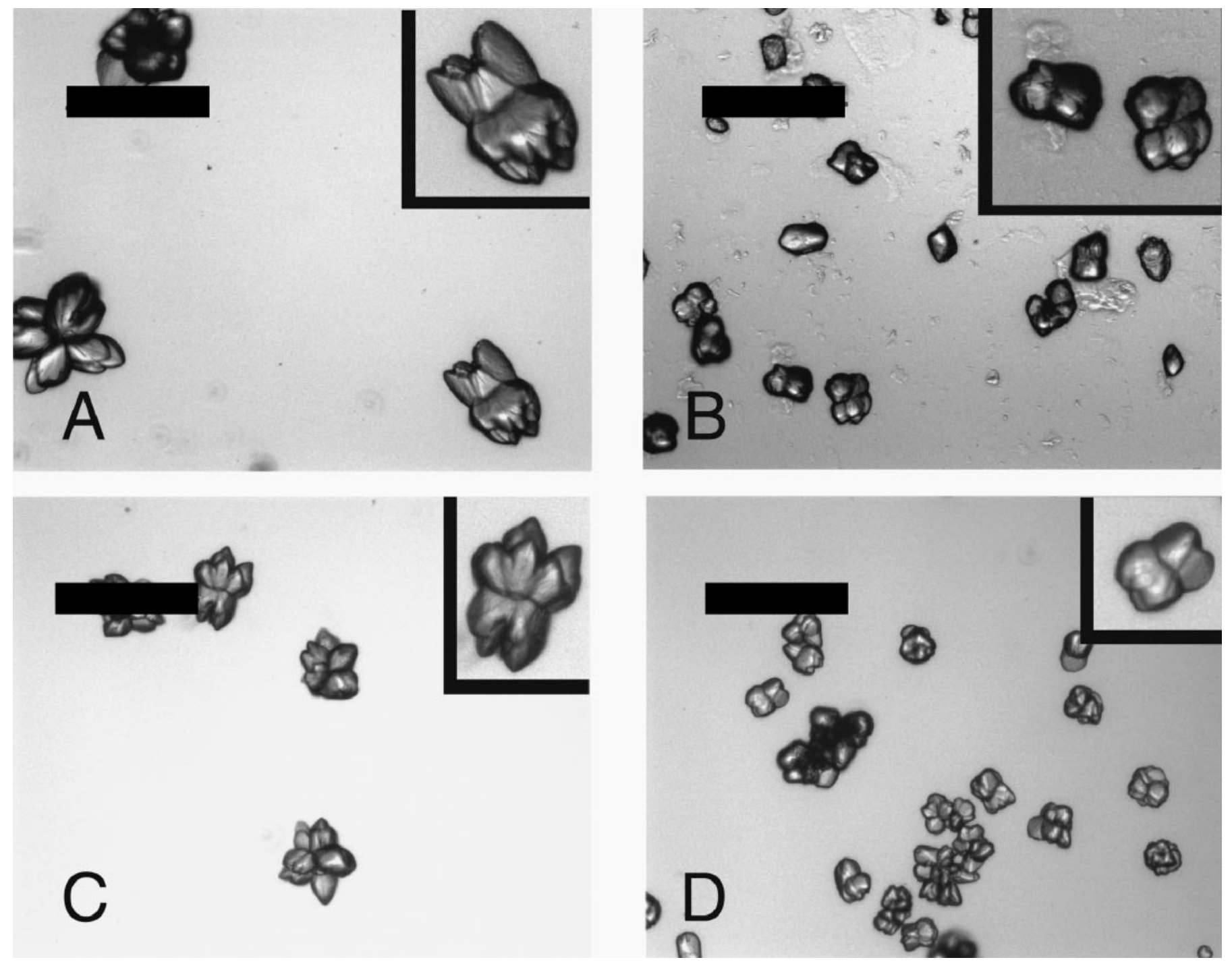

FIG. 6.-EPS and LPS of G20 can change calcite morphology. A) A typical field of view from the control medium without lypopolysaccharide (LPS) in a precipitation experiment concurrent with Part B. B) A typical field of view in the presence of G20 LPS. The crystals are more rounded, less visibly striated, more numerous and smaller relative to Part A. C) A typical field of view from the control medium without exopolymeric substances (EPS) in a precipitate experiment concurrent with Part D. D) A representative field of view in the presence of G20 EPS $(0.125 \mathrm{mg}$ dry EPS $/ \mathrm{ml}$ medium). As in Part B, EPS stimulated the growth of rounded crystals that were less elongated along the $c$ axis, more numerous and smaller relative to Part $\mathrm{C}$. The scale bar in all images is $200 \mu \mathrm{m}$.

Our study supports the results of Braissant et al. (2003) that the presence of less than $0.1 \%$ organic compounds in solution leads to the formation of spherical calcite habits. At a higher initial SI in G20 basal medium with the same organic content, the organic influence diminishes and these habits (Fig. 2A-D) are replaced by rhombohedral calcite habits that are less suggestively biogenic (Fig. 2E-L, Fig. 4A-D). Abundant calcite spheres and dumbbells in natural environments may therefore indicate conditions of relatively low SI in the presence of organic compounds (e.g., EPS or lactate).

However, calcite spherules and other anhedral precipitates may also form under abiotic conditions. Fernández-Díaz et al. (1996) described an abiotic crystallization series of calcium carbonate in a gel and found Mg-calcite spheroids, dumbbells, and other anhedral precipitates at extremely high SI ( $\sim 10$ times higher than the highest SI in our medium). Tracy et al. (1998) reported the formation of spherulites in solutions that contained high concentrations of both magnesium and sulfate. The distinction between biogenic and abiotic spherulites may be possible if the abiotic ones form only in the presence of high sulfate and magnesium, and incorporate more mag- nesium or sulfate than the spherulites within biofilms. A comparative study of the bulk content and the zoning of trace sulfate, magnesium, and organic compounds in inorganically and biologically formed spherulites could help determine whether similar natural precipitates are biogenic or not. Biologically influenced end members could be distinguishable from the abiotic precipitates if they contain very low amounts of $\mathrm{Mg}$ and $\mathrm{SO}_{4}$.

\section{Effects of G20 Cellular Fractions and Biofilms on Calcite Morphology}

Calcite crystals grown in the presence of G20 had more rounded edges than their counterparts in the sterile controls or UV-inhibited cultures (Fig. $1 \mathrm{~A}-\mathrm{C}$ ). Because none of the previously examined parameters (SI, sulfate, lactate) could fully account for this observation, it seemed likely that some kinetic inhibitors associated with metabolically active G20 cells and biofilms could explain this observation. In pursuit of these inhibitors, we compared the potential effects of specific compounds and cellular fractions of G20 that are in contact with the growing crystals in active cultures. G20 colonizes the growing calcite crystals (Fig. 5A) and secretes exopolymeric 
substances (EPS) (Fig. 5B) that are a complex mixture of proteins, nucleic acids, uronic acids, and other polysaccharides (e.g., Beech et al. 1991). The outer part of G20's outer membrane (G20 is a Gram-negative bacterium) contains lypopolysaccharide (LPS) (Ferris 1989). Lypopolysachharide consists of a hydrophobic lipid A, the core polysaccharide, and the $\mathrm{O}$-antigen. The latter two components are rich in carboxyl and phosphoryl residues (Ferris 1989).

Both purified LPS and EPS rounded the edges of calcite crystals in vitro (Fig. 6), when added at a mass concentration that was approximately two orders of magnitude greater than in G20 cultures. We did not observe a similar effect in the presence of the outer membranes (not shown). The crystallites formed in the presence of EPS and LPS were also smaller and more numerous than the ones in control solutions without EPS and LPS added (Fig. 6), suggesting a role for these compounds in the nucleation of calcite (Bosak and Newman 2003).

The difference in bacterial attachment and the secretion of EPS between live and UV-inhibited cultures may provide a clue about the differences between the calcite shapes in these cultures. Active G20 can attach to the growing mineral surface and locally expose crystals to high concentrations of LPS (Fig. 5A). In contrast, dead G20 and purified outer membranes sediment at the bottom of the culture wells to an average height less than $3 \mu \mathrm{m}$ and can stick only to the lowermost surface of the growing calcite crystals ( $>10 \mu \mathrm{m}$ high). Moreover, given that we washed both the uninhibited and the UV-inhibited cells before the precipitation experiment to remove EPS, rounded crystal edges in metabolically active cultures appear to result mainly from the secretion of new EPS (Fig. 5B). A similarly low amount of organics can be expected to affect calcite morphology in natural microbial biofilms. Namely, the secretion of small amounts of kinetic inhibitors (e.g., EPS, LPS) very close to the growing crystal could suffice to change the crystal habit, even when the concentrations of dissolved organics in the bulk solution is low.

Rounding of calcite edges due to the development of high-index faces has been observed in some studies of the effects of carboxylic acids, amino acids, and proteins on calcite morphology (Contos et al. 2001; JimenezLopez et al. 2003; Mann et al. 1990; Meldrum and Hyde 2001). Chemical analysis (two independent experiments) showed that EPS from G20 cultures contained $3 \pm 1 \mu \mathrm{g} / \mathrm{mg}$ EPS more protein than the background sterile medium. Qualitative gel assay confirmed that EPS from G20 cultures also contained more nucleic acids (data not shown), $0.10 \pm 0.01 \mu \mathrm{g} / \mathrm{mg}$ EPS more uronic acids, and $9 \pm 6 \mu \mathrm{g} / \mathrm{mg}$ EPS less carbohydrates than the background medium. These chemical differences are consistent with the hypothesis that negatively charged moieties of G20 EPS (as found in protein, DNA, RNA, and uronic acids) bind calcium or even incorporate into the growing crystals, inhibiting the growth or twinning along some crystal plains. A higher carbohydrate content (neutral sugars) in the sterile medium may be due to the unmetabolized components of the yeast extract and suggests that the net observed differences between active cultures and controls may be partially due to the metabolic alteration of complex organic additives (yeast extract and vitamins) by G20. Unfortunately, rounded edges and curved surfaces of rhombohedral calcite alone are not a good biomarker, inasmuch as similar features have been reported in presumably inorganic solutions at extreme supersaturation values (Gonzalez et al. 1992).

\section{CONCLUSIONS}

In summary, calcite crystals that precipitated in metabolically active cultures of $D$. desulfuricans $\mathrm{G} 20$ were morphologically distinct from the precipitates in sterile controls and UV-inhibited cultures. Biological mechanisms that provide consistent explanations of these differences are: microbial removal of kinetically inhibiting metabolites (sulfate, lactate and, likely, minor inorganic and organic nutrients), the concurrent secretion of EPS, and the interactions between the growing crystals and the LPS of actively colonizing bacteria. On the other hand, both our calculations and our measurements show that microbially induced shifts in the SI were much less important, because the medium is well buffered by high DIC. This is consistent with the model of Arp et al. (2001) where calcification within biofilms in the presence of comparably high DIC occurs within the EPS, instead of being induced by photosynthetic changes of SI on the sheaths of photosynthetic bacteria. Because calcification within biofilms can be kinetically stimulated or inhibited relative to the outside environment at the microscale, it is important for studies to be performed at this scale in the search for robust morphological indicators of bacterial presence (Bosak et al. 2004).

Overall, although we could expect rapid nucleation of many small crystal grains (whitings), due to the high SI of our medium, we found that fewer large crystals grew instead. This appears to be caused by the presence of many kinetic inhibitors in the solution. Our results show that microbes can exert kinetic control not only by the secretion of exopolymeric substances (Arp et al. 1999; Braissant et al. 2003) but also by the active uptake (or release) of primary organic and inorganic metabolites. Extending these observations to the field, we infer that microbial production or removal of kinetic inhibitors may have controlled calcification within biofilms in highly supersaturated environments, both ancient (Precambrian oceans) and modern (soda lakes and travertine deposits).

\section{ACKNOWLEDGMENTS}

We want to thank George Rossman and Ma Chi of the Division Analytical Center, Benjamin Weiss, Virginia Souza-Egipsy, Megan Ferguson and Nathan Dalleska, John Grotzinger, Andy Knoll, Bruce Fouke, Henry Chafetz, two anonymous reviewers, and the members of the Newman laboratory for their help, comments, and suggestions. This work was supported by grants from the Agouron Institute, the Luce Foundation, and the Packard Foundation.

\section{REFERENCES}

Allison, D.G., and Sutherland, I.W., 1984, A staining technique for attached bacteria and its correlation to extracellular carbohydrate production: Journal of Microbiological Methods, v. 2, p. 93-99.

Anbar, A.D., and Knoll, A.H., 2002, Proterozoic ocean chemistry and evolution: A bioinorganic bridge?: Science, v. 297, p. 1137-1142.

Arp, G., Hofmann, J., and Reitner, J., 1998, Microbial fabric formation in spring mounds ("Microbialites") of alkaline salt lakes in the Badain Jaran Sand Sea, PR China: Palaios, V. 13 , p. 581-592.

Arp, G., Reimer, A., and Reitner, J., 2001, Photosynthesis-induced biofilm calcification and calcium concentrations in Phanerozoic oceans: Science, v. 292, p. 1701-1704.

Arp, G., Thiel, V., Reimer, A., Michaelis, W., and Reitner, J., 1999, Biofilm exopolymers control microbialite formation at thermal springs discharging into the alkaline Pyramid Lake, Nevada, USA: Sedimentary Geology, v. 126, p. 159-176.

Astilleros, J.M., Pina, C.M., Fernández-Díaz, L., And Putnis, A., 2002, Molecular-scale surface processes during the growth of calcite in the presence of manganese: Geochimica et Cosmochimica Acta, v. 66, p. 3177-3189.

BeEch, I.B., Gaylarde, C.C., Smith, J.J., and Geesey, G.G., 1991, Extracellular polysaccharides from Desulfovibrio desulfuricans and Pseudomonas fluorescens in the presence of mild and stainless steel: Applied Microbiology and Biotechnology, v. 35, p. 65-71.

Berner, R.A., AND Morse, J.W., 1974, Dissolution kinetics of calcium-carbonate in sea-water. 4. Theory of calcite dissolution: American Journal of Science, v. 274, p. 108-134.

Blumenkrantz, N., and Asboenansen, G., 1973, New method for quantitative-determination of uronic acids: Analytical Biochemistry, v. 54, p. 484-489.

Bosak, T., and Newman, D.K., 2003, Microbial nucleation of calcium carbonate in the Precambrian: Geology, v. 31 , p. $577-580$

Bosak, T., Souza-Egipsy, V., Corsetti, F.A., and Newman, D.K., 2004, Micron-scale porosity as a biosignature in carbonate crusts: Geology, v. 32, p. 781-784.

BRADFORD, M.M., 1976, Rapid and sensitive method for quantitation of microgram quantities of protein utilizing principle of protein-dye binding: Analytical Biochemistry, v. 72, p. 248254

Braissant, O., Cailleau, G., Dupraz, C., and Verrecchia, A.P., 2003, Bacterially induced mineralization of calcium carbonate in terrestrial environments: the role of exopolysaccharides and amino acids: Journal of Sedimentary Research, v. 73, p. 485-490.

BucZynski, C., AND ChafETZ, H.S., 1991, Habit of bacterially induced precipitates of calciumcarbonate and the influence of medium viscosity on mineralogy: Journal of Sedimentary Petrology, v. 61, p. 226-233.

Chafetz, H.S., Rush, P.F., ANd Utech, N.M., 1991, Microenvironmental controls on mineralogy and habit of $\mathrm{CaCO}_{3}$ precipitates - an example from an active travertine system: Sedimentology, v. 38, p. 107-126. 
Contos, A.K., James, J.M., Heywood, B., Pitt, K., And Rogers, P., 2001, Morphoanalysis of bacterially precipitated subaqueous calcium carbonate from Weebubbie Cave, Australia: Geomicrobiology Journal, v. 18, p. 331-343.

Davis, K.J., Dove, P.M., And De Yoreo, J.J., 2000, The role of $\mathrm{Mg}^{2+}$ as an impurity in calcite growth: Science, v. 290, p. 1134-1137.

Feio, M.J., Beech, I.B., Carepo, M., Lopes, J.M., Cheung, C.W.S., Franco, R., Guezennec, J. Smith, J.R., Mitchell, J.I., Moura, J.J.G., And Lino, A.R., 1998, Isolation and characterisation of a novel sulphate-reducing bacterium of the Desulfovibrio genus: Anaerobe, v. 4, p. $117-130$.

Fernández-Díaz, L., Putnis, A., Prieto, M., and Putnis, C.V., 1996, The role of magnesium in the crystallization of calcite and aragonite in a porous medium: Journal of Sedimentary Research, v. 66, p. 482-491.

FERRIS, F.G., 1989, Metallic ion interactions with the outer membrane of Gram-negative bacteria, in Beveridge, T.J., and Doyle, R.J., eds., Metal Ions and Bacteria: New York, John Wiley \& Sons, Inc., p. 295-323.

Folk, R.L., Chafetz, H.S., And Tiezzi, P.A., 1985, Bizarre forms of depositional and diagenetic calcite in hot-spring travertines, central Italy, in Schneidermann, N., and Harris, P.M., eds., Carbonate Cements: SEPM, Special Publication 36, p. 349-369.

Gerhardt, P., ed., 1994, Methods for General and Molecular Bacteriology: Washington, D.C., American Society for Microbiology, $791 \mathrm{p}$.

Given, R.K., And Wilkinson, B.H., 1985, Kinetic control of morphology, composition, and mineralogy of abiotic sedimentary carbonates: Journal of Sedimentary Petrology, v. 55, p. 109-119.

Gonzalez, L.A., Carpenter, S.J., and Lohmann, K.C., 1992, Inorganic calcite morphologyroles of fluid chemistry and fluid-flow: Journal of Sedimentary Petrology, v. 62, p. 382 399.

Grotzinger, J.P., and James, N.P., 2000, Precambrian carbonates: evolution of understanding, in Grotzinger, J.P., and James, N.P., eds., Carbonate Sedimentation and Diagenesis in the Evolving Precambrian World: SEPM, Special Publication 67, p. 3-20.

Grotzinger, J.P., and Kasting, J.F., 1993, New constraints on Precambrian ocean composition: Journal of Geology, v. 101, p. 235-243.

Grotzinger, J.P., AND KNoll, A.H., 1999, Stromatolites in Precambrian carbonates: Evolutionary mileposts or environmental dipsticks?: Annual Review of Earth and Planetary Sciences, v. 27 , p. $313-358$.

Habicht, K.S., Gade, M., Thamdrup, B., Berg, P., and Canfield, D.E., 2002, Calibration of sulfate levels in the Archean Ocean: Science, v. 298, p. 2372-2374.

Jímenez-López, C., Rodríguez-Navarro, A., Domínguez-Vera, J.M., and García-Ruiz, J.M., 2003, Influence of lysozyme on the precipitation of calcium carbonate: A kinetic and morphologic study: Geochimica et Cosmochimica Acta, v. 67, p. 1667-1676.

Kawaguchi, T., AND Decho, A.W., 2002, A laboratory investigation of cyanobacterial extracellular polymeric secretions (EPS) in influencing $\mathrm{CaCO}_{3}$ polymorphism: Journal of Crystal Growth, v. 240 , p. $230-235$
Klug, H.P., And AleXander, L.E., 1954, X-ray Diffraction Procedures for Polycrystalline and Amorphous Materials: New York, Wiley, 716 p.

Krumbein, W.E., 1978, Photolithotropic and chemoorganotrophic activity of bacteria and algae as related to beachrock formation and degradation (Gulf of Aqaba, Sinai): Geomicrobiology Journal, v. 1, p. 139-203.

Mann, S., Didymus, J.M., Sanderson, N.P., Heywood, B.R., and Aso Samper, E.J., 1990, Morphological influence of functionalized and non-functionalized $\alpha, \omega$-dicarboxylates on calcite crystallization: Journal of the Chemical Society, Faraday Transactions, v. 86, p. 1873-1880. Meldrum, F.C., And Hyde, S.T., 2001, Morphological influence of magnesium and organic additives on the precipitation of calcite: Journal of Crystal Growth, v. 231, p. 544-558.

Онmoto, H., Watanabe, Y., and Kumazawa, K., 2004, Evidence from massive siderite beds for a $\mathrm{CO}_{2}$-rich atmosphere before 1.8 billion years ago: Nature, v. 429, p. 395-399.

Roberts, J.A., Bennett, P.C., Gonzalez, L.A., Macpherson, G.L., and Milliken, K.L., 2004, Microbial precipitation of dolomite in methanogenic groundwater: Geology, v. 32, p. 277 280.

Rodríguez-Navarro, C., Rodríguez-Gallego, M., Ben Chekroun, K., and González-Muñoz, M.T., 2003, Conservation of ornamental stone by Myxococcus xanthus-induced carbonate biomineralization: Applied and Environmental Microbiology, v. 69, p. 2182-2193.

Schultze-Lam, S., Fortin, D., Davis, B.S., and Beveridge, T.J., 1996, Mineralization of bacterial surfaces: Chemical Geology, v. 132, p. 171-181.

Stumm, W., and Morgan, J., 1996, Aquatic Chemistry: Chemical Equilibria and Rates in Natural Waters: New York, John Wiley \& Sons, Inc., 1022 p.

Takasaki, S., Parsiegla, K.I., and Katz, J.L., 1994, Calcite growth and the inhibiting effect of iron(III): Journal of Crystal Growth, v. 143, p. 261-268.

Teng, H.H., Dove, P.M., Orme, C.A., And De Yoreo, J.J., 1998, Thermodynamics of calcite growth: Baseline for understanding biomineral formation: Science, v. 282, p. 724-727.

Thomas-Keprta, K.L., McKay, D.S., Wentworth, S.J., Stevens, T.O., Taunton, A.E., Allen, C.C., Coleman, A., Gibson, E.K., and RomaneK, C.S., 1998, Bacterial mineralization patterns in basaltic aquifers: Implications for possible life in martian meteorite ALH84001: Geology, v. 26 , p. 1031-1034

Tiller, W.A., 1991, The Science of Crystallization: Macroscopic Phenomena and Defect Generation: Cambridge, U.K., Cambridge University Press, 484 p.

Tracy, S.L., Williams, D.A., And Jennings, H.M., 1998, The growth of calcite spherulites from solution II. Kinetics of formation: Journal of Crystal Growth, v. 193, p. 382-388

Van Lith, Y., Warthmann, R., Vasconcelos, C., and McKenZie, J.A., 2003, Microbial fossilization in carbonate sediments: a result of the bacterial surface involvement in dolomite precipitation: Sedimentology, v. 50, p. 237-245.

Visscher, P.T., Reid, R.P., AND BeBout, B.M., 2000, Microscale observations of sulfate reduction: Correlation of microbial activity with lithified micritic laminae in modern marine stromatolites: Geology, v. 28, p. 919-922.

Warthmann, R., van Lith, Y., Vasconcelos, C., McKenzie, J.A., and Karpoff, A.M., 2000, Bacterially induced dolomite precipitation in anoxic culture experiments: Geology, v. 28, p. 1091-1094.

Received 9 October 2003; accepted 2 August 2004. 